\title{
Política (i)migratória brasileira e a construção de um perfil de imigrante desejado: lugar de memória e impasses
}

\author{
Brazilian (im)migration policy and the construction of a desired \\ immigrant profile: place of memory and deadlocks
}

Samira Moratti Frazão ${ }^{1}$

RESUMO

A proposta deste artigo foi refletir sobre o lugar de memória ocupado pela política (i)migratória do Brasil, e seus reflexos nos discursos midiáticos, bem como na história do tempo presente. Para tanto, foram contemplados estudos sobre a legislação brasileira que vigorou durante o final do século XIX, e as transformações ocorridas até os dias atuais, cujo foco central são os fluxos migratórios internacionais. Também foram selecionados trechos de reportagens sobre grupos imigrantes no passado e presente, cruzando a crítica dos decretos e leis examinadas com os discursos midiáticos. Para tanto, foi realizada uma análise comparativa, a fim de verificar pontos consonantes e dissonantes na legislação do passado e o que ainda emerge no presente, seja através do instrumento legal em vigor, e/ou das narrativas midiáticas.

Palavras chave: Fluxos imigratórios contemporâneos; Política (i)migratória brasileira; Lugar de memória; Mídia.

ABSTRACT

The proposal of this article was reflected in the place of memory occupied by the (i)migratory politics of Brazil and its reflections in the media discourses. In order to do so, studies on a Brazilian legislation that were in force during the end of the 19th century were contemplated, as well as the transformations occurring until the present day, the central focus is the international immigratory flows. It was also selected news reports on immigrant groups in the present, intersecting a critique of the decrees and laws examined with the media discourses. In order to do so, a comparative analysis was carried out, observing consonants and dissonants points in the legislation of the past that still emerges in the present, by the current legal instrument, and / or media narratives.

Keyword: Contemporary immigratory flows; Brazilian (i)migration policy; Place of memory; Media.

1 - Programa de Pós-Graduação em História da Universidade do Estado de Santa Catarina (PPGH/UDESC). 
Para refletir sobre os acontecimentos recentes compreendendo fluxos migratórios internacionais para o Brasil na contemporaneidade, é necessário mirar o passado. Para esse exercício, foram analisados instrumentos legais, utilizados outrora pelo Governo, para legitimar ou não um perfil ou perfis de imigrantes considerados como desejados para entrar e permanecer em solo brasileiro. Por meio dos órgãos responsáveis por fiscalizar a migração, e veículos jornalísticos que integraram e/ou ainda fazem parte da mídia brasileira, o Governo e seus líderes fizeram valer uma política migratória que, em algumas situações, marginalizou determinados grupos imigratórios.

Essas marcas que tornam a aparecer e permanecem no contemporâneo pela via jurídica, cujas características também são apresentadas na mídia por meio de reportagens a respeito dos fluxos migratórios internacionais, não devem ser desconsideradas. É preciso refletir o caráter influenciável que carregam para qualificar ou não determinados grupos imigrantes, motivados por questões econômicas ou que estão em uma situação de refúgio em virtude de fatores como guerras, conflitos civis, dentre outros. Se considerarmos a legislação enquanto um lugar de memória, em alusão aos estudos postulados pelo historiador francês Pierre Nora, logo, pode acarretar desdobramentos negativos e/ou positivos na compreensão pública da sociedade sobre os fluxos imigratórios contemporâneos para e no Brasil.

Para avaliar a problemática apresentada, foram contemplados estudos sobre as políticas migratórias brasileiras que vigoraram durante o final do século XIX e aquela em vigor no presente, cujo foco central sejam os fluxos migratórios internacionais. Recorreu-se à dez decretos e leis que vigoraram entre 1824 e 1980, ano de criação do Estatuto do Estrangeiro. Também foram selecionados trechos de reportagens sobre fluxos imigratórios no passado e presente, cruzando a crítica da referida legislação com os discursos midiáticos. Para tanto, foi realizada uma análise comparativa, a fim de verificar pontos consonantes e dissonantes na referida legislação e o que ainda emerge no presente, seja através do instrumento legal vigorante, ou dos discursos que emanam na mídia.

\section{Lugar de memória: breve reflexão sobre o conceito}

Antes de realizar a análise da legislação do passado e da contemporaneidade, faz-se necessário tratar acerca do conceito de lugar de memória, assim como a própria relação entre a história e a memória. Para tanto, serão adotados os estudos do historiador francês Pierre Nora, referência no tema. Ainda que seja complexo determinar um significado primaz sobre os conceitos de memória e história, e ressalta-se que esta não é a intenção do presente estudo, foi preciso delimitar aqui um ponto de partida para aprofundar o debate escolhendo, portanto, um dentre muitos.

Para Pierre Nora, a memória caminha em um movimento de transformação constante, sendo revitalizada, interpretada, passível, portanto, de alterações em seu curso e esquecimentos (NORA, 1993). É, ao mesmo tempo, coletiva e individual, e faz emergir no presente resquícios do 
passado através de objetos, sons, imagens estáticas e audiovisuais, além da própria oralidade passada de geração a geração por um grupo social. A história, por sua vez, é “... a reconstrução sempre problemática e incompleta do que não existe mais” (NORA, 1993, p. 9). E continua:

Tudo o que é chamado hoje de memória não é, portanto, memória, mas já história. Tudo o que é chamado de clarão da memória é a finalização do seu desaparecimento no fogo da história. A necessidade de memória é uma necessidade da história. (NORA, 1993, p. 14)

Ou seja, a partir de uma análise crítica pela história o passado pode ganhar vida por intermédio de representações, interpretações feitas com base em vestígios materializados em documentos, arquivos ou relatos daqueles que viveram em um determinado período histórico (NORA, 1993). Caberia à história refutar a memória e extrair dela o crível e o lógico.

E o que vem a ser os lugares de memória nesse contexto? Segundo Nora, seriam “... restos. A forma extrema onde subsiste uma consciência comemorativa numa história que a chama, porque ela a ignora" (NORA, 1993, p. 12-13). Para ser mais exato em sua definição, o historiador exemplifica tais lugares como redutos físicos e simbólicos, heranças de grupos de um tempo que não existe mais, com três características específicas e que são coexistentes: lugares materiais, simbólicos e funcionais. "Museus, arquivos, cemitérios e coleções, festas, aniversários, tratados, processos verbais, monumentos, santuários, associações, são os marcos testemunhais de uma outra era, das ilusões de eternidade" (NORA, 1993, p. 13).

Uma necessidade, portanto, de uma sociedade acelerada, que ambiciona um futuro que ainda não lhe pertence, preocupada em não fazer viver a memória. Relega, desse modo, aos repositórios físicos e imateriais a incumbência de perpetuar uma memória sobre determinado acontecimento ou momento que se viveu. Na ausência de uma memória espontânea vivida coletivamente, caberia aos historiadores a função de conferir sentido a esses lugares de memória, por meio da crítica e da problematização dos resquícios que ali habitam. E, nessa operação historiográfica, traduzir à sociedade sentidos possíveis sobre suas versões institucionalizadas.

Segundo Nora (1993), para se tornar um lugar de memória, é preciso que haja a intenção, uma vontade de memória. No caso da problemática apresentada no presente estudo, quando evocadas direta ou indiretamente, seja através de decretos e leis ou de espaços como a mídia e o jornalismo em suas diversas plataformas, a legislação aqui tomada como objeto empírico de análise pode se tornar um lugar imaterial de memória. Em determinados casos, como os que serão expostos adiante, tais redutos memoriais podem ser discriminatórios.

O processo de rememorar, porém, traz consigo subjetividades, lapsos e o esquecimentos, de modo que o lembrar jamais trará a tona a vivência real (HALBWACHS, 1990). Desse modo, o lugar de memória poderia auxiliar quem dele se vale a relembrar um tempo que não existe 
mais. No entanto, esse reconstruir a história requer crítica e ambivalência, uma vez que os vestígios apresentados podem não corresponder, de fato, ao que representam.

\section{Leis do passado e presente e o lugar ocupado na memória social}

A migração está relacionada com a criação no Brasil desde seus primórdios. E mesmo sendo um componente histórico do país, é encarado em determinadas ocasiões como um problema que precisa ser contido em esfera midiática, governamental e jurídica. Barreto sintetiza brevemente a relação do Brasil com a migração, para iniciar esse retorno ao passado:

A imigração no Brasil começou com os próprios descobridores, os portugueses, no processo de colonização. Posteriormente, com o desenvolvimento da lavoura, principalmente para exportação, tivemos a imigração forçada de africanos que chegaram ao Brasil como escravos. Entretanto, com o fim da escravidão, tornou-se imperiosa a vinda de imigrantes para suprir a necessidade de mãode-obra para as pequenas propriedades, que objetivavam o desenvolvimento e a segurança do sul do país, bem como para a lavoura cafeeira de exportação. Nesse contexto, chegaram italianos, alemães e japoneses (BARRETO, 2001, p. 64)

É preciso, porém, fazer um parêntese importante em tal citação. Não que não houvesse mãode-obra no país, pois de certo que havia uma grande quantidade de pessoas escravizadas no passado e que gozavam de liberdade, porém sem nenhum tipo de suporte do governo ou de seus algozes. Ainda que pesquisas quantitativas não deem conta da realidade tal qual foi, estima-se que 5.848.266 milhões de africanos foram trazidos forçadamente ao Brasil entre os anos $1501 \mathrm{e}$ 1875 para serem escravizados ${ }^{1}$. De acordo com um relatório anual apresentado pelo Ministério da Agricultura, estima-se que em 1887 havia no país 723.419 pessoas escravizadas, um ano antes da assinatura da Lei Áurea, em 13 de maio de 1888, que culminou com a Abolição da escravidão (MARINGONI, 2011). Ainda que não haja estimativas sobre o número de africanos libertos, o dado é relevante para se ter uma dimensão da quantidade de pessoas, antes escravizadas. Enquanto necessitavam de emprego e de políticas reparatórias à escravidão imposta, a solução encontrada pelo governo foi outra, cuja proposta em trazer imigrantes, principalmente os de origem europeia para o Brasil, possuía o apelo de embranquecer a população local.

A entrada de estrangeiros no Brasil, embora com franca ocorrência desde a vinda de portugueses em 1500, intensificou-se com o decorrer dos séculos, em especial com a abolição da escravatura e a adoção de políticas eugênicas, que privilegiaram os imigrantes de origem

${ }^{1} \mathrm{O}$ dado foi apresentado no projeto internacional www.slavevoyages.org, sobre o tráfico de africanos para várias partes do mundo, como Uruguai, Brasil, Grã Bretanha, Estados Unidos, França, dentre outros. A iniciativa foi liderada pela Universidade de Emory (Atlanta, EUA), em parceria com historiadores brasileiros, como é o caso de Manolo Garcia Florentino, do Departamento de Historia da Universidade Federal do Rio de Janeiro (UFRJ), além de historiadores da Nova Zelândia, Inglaterra, Canadá e Estados Unidos. Os dados aqui apresentados foram consultados em: http://slavevoyages. org/assessment/estimates, em 31 mar. 2017. 
europeia em detrimento dos de origem africana e/ou de outras nacionalidades, ou ainda àqueles que, de forma forçada ou voluntária, vieram ao Brasil sem possuir pele branca e sangue europeu (MENEZES, 2001).

Mesmo com a substituição de pessoas escravizadas por uma mão-de-obra livre, composta por imigrantes europeus e considerada industriosa, cuja característica fez parte de uma política de branqueamento da população e de seletividade migratória para ocupar algumas regiões brasileiras, notadamente o sul do país, os espaços ocupados por esses imigrantes europeus não eram necessariamente "vazios demográficos", se considerarmos as populações indígenas ali presentes e que foram dizimadas e extintas pelo homem branco de forma gradual, até os dias atuais (ASSIS, 2012).

A respeito de tal política migratória brasileira, Lená Medeiros de Menezes diz que

A preocupação governamental com os espaços vazios ensejou algumas tentativas de atração de imigrantes visando ao povoamento principalmente dos territórios de fronteira com as colônias espanholas. Essa preocupação tornouse projeto continuado com a Independência, projetando-se, a partir de então, como uma das vertentes permanentes das políticas imigratórias oficialmente desenvolvidas, que só conheceu estancamento na década de 1970. (MENEZES, 2001, p. 124)

Essas reminiscências do passado estão dispostas nos decretos eleis migratórias vigentes entre os séculos XIX e XX e aqui resumidamente examinadas. Tal análise tomou como fio condutor a migração e posterior colonização para fins laborais e ocupação de "vazios demográficos" no Brasil. Para tanto, foram consultados estudos de referência como os postulados por Giralda Seyferth (1994; 2000; 2001), Lená Medeiros de Menezes (2001) e Marcílio Ribeiro de Sant’Anna (2001), dentre outros, associado à análise direta dos artigos dos decretos e leis citadas, tomados como fontes da pesquisa.

\section{Análise das fontes}

Tomou-se como ponto de partida a decisão de número 80, de 31 de março de 1824 . Por meio dela, D. Pedro I estabeleceu que as terras da colônia alemã São Leopoldo, na Província de São Pedro do Sul - atual estado do Rio Grande do Sul -, fossem reconhecidas pelo Império como um local onde imigrantes europeus, sobretudo alemães, poderiam contribuir para o desenvolvimento nacional (SANT'ANA, 2001). O intuito era o de fundar colônias agrícolas, especialmente nos estados do Rio Grande do Sul e, posteriormente, Santa Catarina e Paraná, todos na região sul. 
Esperando-se brevemente nesta Côrte uma Colônia de Alemães, a qual não pôde deixar de ser reconhecida utilidade para este Imperio, pela superior vantagem de se empregar gente branca livre e industriosa, tanto nas artes quanto na agricultura (BRASIL, 1824, p. 58) ${ }^{2}$

No contexto das grandes ondas migratórias iniciadas no século XIX e cujo fluxo perdurou durante o século $\mathrm{XX}$, as discussões em torno da predileção por imigrantes de origem europeia possuem como pano de fundo a ideologia de branqueamento. É oportuno, portanto, tratar acerca desta questão, uma vez que por meio dela é possível compreender o processo de construção do perfil de um imigrante considerado desejado, branco e europeu, e que ocorreu nas esferas política e social.

O debate de fundo político e ideológico instaurado no Brasil em parte da sociedade civil e da esfera política e governamental, tomou a ideologia do branqueamento como um caminho para embranquecer a população (CARONE, 2002; MUNANGA, 2002). Uma das bases para sua concepção no Brasil desde o final do século XIX foi a teoria científica de Joseph Arthur de Gobineau, situada em uma visão poligenista da sociedade, ou seja, que concebia a existência de diversas linhas para a existência da humanidade, e segundo a qual o "cruzamento inter-racial" era condenado (CARONE, 2002, p. 14). Entre juristas positivistas que defendiam a miscigenação como fator para setorizar a sociedade entre aqueles considerados aptos a "civilizar, tutelar ou absorver as raças com desenvolvimento num estágio inferior" (CARONE, 2002, p. 15), também haviam aqueles que argumentavam em favor da industrialização do Brasil com o emprego de uma mão-de-obra branca e europeia que, para eles, estaria familiarizada às práticas capitalistas industriais necessárias à industrialização econômica do Brasil (CARONE, 2002). Dessa forma, recorreu-se à adoção de políticas que estimulassem a vinda de imigrantes europeus para auxiliar no desenvolvimento do país, no que diz respeito à economia e ao branqueamento da população.

Dando continuidade à análise das fontes, a Lei de número 601, de 18 de setembro de 1850, conhecida como Lei de Terras, foi um dos marcos da implementação da política migratória no Brasil. A partir de seus artigos, é possível notar que a vinda de imigrantes era associada ao agenciamento, por parte de representantes do governo brasileiro, os quais se utilizavam de "métodos de aliciamento utilizados durante o Primeiro Reinado" (SEYFERTH, 2001, p. 138), contando ainda com propagandas sobre o país aos possíveis imigrantes, as quais prometiam a “... concessão de terras férteis, subsídios e passagens (nem sempre concretizadas)” (SEYFERTH, 2001, p. 138). Naquele momento, a predileção por imigrantes alemães se dava por considerá-los bons agricultores e que se adaptariam melhor no país, em comparação com pessoas de outras nacionalidades.

\footnotetext{
${ }^{2}$ Ressalta-se que nas citações diretas foi mantida a grafia original da época, descrita nos decretos e leis analisados.
} 
De acordo com o artigo 18 da Lei de Terras:

Art. 18. O Governo fica autorizado a mandar vir annualmente á custa do Thesouro certo numero de colonos livres para serem empregados, pelo tempo que for marcado, em estabelecimentos agricolas, ou nos trabalhos dirigidos pela Administração publica, ou na formação de colonias nos logares em que estas mais convierem; tomando anticipadamente as medidas necessarias para que taes colonos achem emprego logo que desembarcarem. Aos colonos assim importados são applicaveis as disposições do artigo antecedente. (BRASIL, 1850)

Um dos fatores pela predileção de alemães naquele contexto político também se deu em virtude da não-aceitação de outros grupos imigrantes que tentaram aqui se estabelecer, como chineses, franceses, belgas e irlandeses, e que protestaram contra a administração colonial considerada inadequada. Um dos casos, ocorrido na região do Vale do Itajaí em um período que compreendeu os anos de 1860 e 1870, foi um dos fatores pelos quais houvesse uma rejeição pela vinda de outros grupos europeus ao Brasil (SEYFERTH, 2001).

Além disso, entre os imigrantes indesejados estavam os negros, chineses e hindus, considerados como "raças inferiores" (SEYFERTH, 2001, p. 139). A política imperial, então, determinava que a concessão de terras públicas para a intervenção e moradia de imigrantes só era permitida para aqueles que possuíssem talento com a agricultura, ou em cujo país de origem houvesse um histórico de sucesso nesse tipo de atividade, bem como a pele branca, características consideradas como ideais para o desenvolvimento do país (SEYFERTH, 2001). Nesse contexto, os imigrantes de origem europeia privilegiados foram inicialmente os alemães, seguidos de italianos, espanhóis, suíços e também poloneses, abrindo raras exceções a outras nacionalidades.

No início do século XX, meados da Primeira República no Brasil, houve uma diminuição no fluxo de imigrantes europeus para o país. A fim de mudar esse cenário, estabeleceu-se o Decreto n. 528 de 28 de junho de 1890, responsável por regulamentar o Serviço de Introdução e Localização de Imigrantes. A partir de então era declarada livre a entrada de indivíduos no Brasil para trabalhar no país, exceto aqueles provenientes da Ásia e África e indígenas, que somente teriam sua entrada permitida mediante aprovação do Congresso Nacional (SANT'ANA, 2001). Logo, a política migratória privilegiava questões econômicas e eugênicas, além de visar a construção de uma nação unificada nos padrões que os governantes e a elite desejavam. Além disso, a referida lei também citava fatores como gênero, idade e capacitismo, a ver em seu artigo quinto:

Art. $5^{\circ}$ Sómente terão passagem integral ou reduzida, por conta do Governo Federal: $1^{\circ}$ As familias de agricultores, limitados aos respectivos chefes, ou aos seus ascendentes os individuos maiores de 50 annos; $2^{\circ}$ Os varões solteiros 
maiores de 18 annos e menores de 50, uma vez que sejam trabalhadores agricolas; $3^{\circ}$ Os operarios de artes mecanicas ou industriaes, artezãos e os individuos que se destinarem ao serviço domestico, cujas idades se acharem comprehendidas entre os limites do paragrapho precedente. Os individuos enfermos ou com defeitos physicos, sómente terão passagem gratuita, si pertencerem a alguma familia que tenha pelo menos duas pessoas válidas. (BRASIL, 1890)

Anos depois foi regulamentado o Serviço de Povoamento, vinculado ao Ministério da Agricultura, Indústria e Comércio pelo Decreto n. 9.081 de 3 de novembro de 1911. As promessas aos imigrantes eram as mesmas praticadas anteriormente, com a subvenção de terras por parte do governo brasileiro, que agia por meio dos seus representantes, os quais agenciavam a vinda dos imigrantes para cá. Tal prática de subsídio às imigrações, a mesma durante o Brasil Império, foi considerada necessária, uma vez que era baixo o contingente de imigrantes espontâneos, que vinham para o país por vontade própria, sem a subvenção financeira do governo brasileiro (SEYFERTH, 2001).

Assim como no decreto anterior, neste publicado em 1911 também eram claras as características do perfil desejado para imigrantes, incluindo idade, gênero, nível social, bem como os fatores proibitivos relativos à "condições morais" para sua entrada no país, concernentes à idade, capacitismo e pobreza. Como é o caso dos artigos segundo, quarto e de número onze:

Art. $2^{\circ}$. Para os effeitos do artigo anterior serão acolhidos como immigrantes os estrangeiros menores de 60 annos, que, não soffrendo de doenças contagiosas, não exercendo profissão illicita, nem sendo reconhecidos como criminosos, desordeiros, mendigos, vagabundos, dementes, ou invalidos, chegarem aos portos nacionaes com passagem de $2^{\mathrm{a}}$ ou $3^{\mathrm{a}}$ classe, á custa da União, dos Estados ou do terceiros (...) Art. $4^{\circ}$. O Governo Federal dirige e auxilia, de accôrdo com os Estados, e sem embargo de acção identica por parte destes, a introducção e localização de immigrantes que, reunindo as condições moraes expressas no art. $2^{\circ}$, sendo agricultores e vindo acompanhados de familia ou a chamado da mesma, quizerem localizar-se no paiz como proprietarios rurais (...). Art. 11. Os representantes do Brazil e os encarregados do serviço de immigração no exterior usarão de todos os meios precisos para evitar a vinda como immigrantes de passageiros de $2^{\mathrm{a}}$ e $3^{\mathrm{a}}$ classes, que não possam ser acolhidos nos termos do art. $2^{\circ}$ deste decreto. (BRASIL, 1911)

As características desejadas e indesejadas dos imigrantes também constavam no Decreto de número 4.247, publicado em 6 de janeiro de 1921. A seguir, referencia-se o artigo primeiro: 
Art. $1^{\circ}$ E' licito ao Poder Executivo impedir a entrada no territorio nacional: $1^{\circ}$, de todo estrangeiro nas condições do art. $2^{\circ}$ desta lei; $2^{\circ}$, de todo estrangeiro mutilado, aleijado, cego, louco, mendigo, portador de molestia incuravel ou de molestia contagiosa grave; $3^{\circ}$, de toda estrangeira, que procure o paiz para entregar-se á prostituição; $4^{\circ}$, de todo estrangeiro de mais de 60 annos. (BRASIL, 1921)

Para Menezes, os imigrantes europeus vieram ao Brasil motivados por “... novas condições de existência, pobres e ingênuas o suficiente para dependerem de políticas de subvenção e se deixarem levar por propagandas enganosas" (MENEZES, 2001, p. 125), como as descritas nos decretos e leis analisadas.

Da década de 1930 em diante, a política sob esses viés continuou em vigor, muito embora apresentasse ambiguidades. Para Sant'ana: “... ao mesmo tempo em que afirmam a necessidade de integração/assimilação de estrangeiros à nacionalidade, sublinham sua condição de estrangeiros e os submetem a normas discriminatórias" (SANT'ANA, 2001, p. 74). No contexto do Estado Novo (1937-1945) em virtude, sobretudo, de questões políticas, a cultura estrangeira não deveria ser fomentada. Por exemplo, o Decreto-Lei n. 406, de 4 de maio de 1938 descreve em seus artigos de número 85 e 86 :

Art. 85. Em todas as escolas rurais do pais, o ensino de qualquer matéria será ministrada em português, sem prejuízo do eventual emprego do método direto no ensino das línguas vivas. $\S 1^{\circ}$ As escolas a que se refere este artigo serão sempre regidas por brasileiros natos. $\S 2^{\circ}$ Nelas não se ensinará idioma estrangeiro a menores de quatorze (14) anos. $\S 3^{\circ}$ Os livros destinados ao ensino primário serão exclusivamente escritos em línguas portuguesa. $\S 4^{\circ}$ Nos programas do curso primário e secundário é obrigatório o ensino da história e da geografia do Brasil. Art. 86. Nas zonas rurais do país não será permitida a publicação de livros, revistas ou jornais em línguas estrangeira, sem permissão do Conselho de Imigração e Colonização. (BRASIL, 1938a)

A imprensa abordou a questão em torno dos imigrantes indesejados a partir do século XIX e meados do século XX. De acordo com Menezes (2001) antes do final da Primeira Guerra Mundial, em 1917, os jornais noticiavam casos de expulsão de imigrantes considerados indesejados, por conta de fatores como o suposto envolvimento com movimento operário, anarquismo, além de outras práticas consideradas à época como perigosas, dispostas no artigo 113 do Decreto $\mathrm{n}$. 3.010, de 20 de agosto de 1938, que regulamenta o decreto anterior, promulgado em maio do mesmo ano. "Art. 113. Serão impedidos de desembarcar, mesmo com o visto consular em ordem, os estrangeiros: (...) III, anarquistas, terroristas, extremistas e congêneres" (BRASIL, 1938b). 
Apesar de os imigrantes de origem europeia constituírem de forma clara e direta, em determinado momento histórico, um grupo priorizado na política migratória brasileira com uma hierarquia que estabelecia os mais desejáveis segundo a origem nacional (alemães, italianos, portugueses, espanhóis e poloneses, por exemplo), tal política de imigrantes considerados desejados foi modificada. Nesse contexto, estes mesmos imigrantes passaram a ser vistos como uma ameaça à constituição de uma nação brasileira, por não se assimilarem à cultura nacional (ASSIS, 2012; SEYFERTH, 1994; 2001).

Tanto a migração chinesa e japonesa quanto a alemã eram vistas como perigos. Sobre o "perigo amarelo" e o "perigo alemão", Giralda Seyferth (2001, p. 145) diz que ambos estariam associados a um receio de que tanto japoneses quanto alemães poderiam colonizar o Brasil seguindo orientações políticas e ideológicas distintas do que se desejava para o país e para os imigrantes que aqui se estabeleciam.

Nesse ínterim, Giralda detalha: "Há, porém, uma sutil diferença que se observa nos dois casos, reportada à ideia de raça. 'Perigo amarelo', na discussão das restrições à imigração, significava 'risco' para o sentido pretendido para a miscigenação - isto é, branqueamento" (SEYFERTH, 2001, p. 145). No que diz respeito ao "perigo alemão", a autora destaca os problemas apontados pelo governo brasileiro à época relacionados a não assimilação desse grupo imigrante em particular, que mesmo no Brasil mantinha a prática do seu idioma nativo, a manutenção de manifestações culturais de seu país de origem, o hasteamento de bandeiras de outros países ou mesmo a demonstração de algum tipo de fidelidade considerada suspeita, o que no contexto político do Estado Novo poderia ser considerado uma afronta à soberania nacional (SEYFERTH, 1994; MENEZES, 2001). Aos olhos do governo brasileiro, os imigrantes alemães e seus descendentes que viviam no Brasil mantendo suas características de origem (cultura, idioma, dentre outros aspectos) poderiam servir como "instrumento do imperialismo germânico" em voga naquele momento, constituindo uma "ameaça à integridade nacional" brasileira (SEYFERTH, 1994, p. 8).

Embora utilizasse o princípio da assimilação para determinar quais nacionalidades poderiam ser melhor assimiladas com os critérios desejados para a entrada e permanência de imigrantes no Brasil, a questão racial pesava na aceitação do imigrante considerado desejado e ideal para participar do processo colonizatório brasileiro, assim como estabelecer uma unidade nacional do país. Porém, durante o Estado Novo no Brasil, especialmente durante a Segunda Guerra Mundial, os imigrantes passaram por um processo de subordinação às culturas e identidades brasileiras, com o intuito de forçar essa assimilação, que ia desde a proibição de línguas estrangeiras nas escolas, assim como o uso de idiomas que não o português no cotidiano desses imigrantes. Assim sendo, japoneses, alemães, judeus, dentre outros acabavam por serem considerados como "inassimiláveis" e/ou "minorias incômodas" (SEYFERTH, 2001, p. 146), fator pelo qual o governo impôs a política de que era necessário haver mais nacionais 
que imigrantes nos núcleos coloniais. Estima-se que quanto o percentual mínimo desejado de nacionais era de $35 \%$, em contrapartida o máximo permitido para cada nacionalidade considerada exterior era de $25 \%$ (SEYFERTH, 2001).

A restrição aos imigrantes continuou no Estado Novo com o Decreto-Lei n. 3.175, de 7 de abril de 1941. Em seu artigo segundo, descreve que fica suspensa a concessão de vistos permanentes. Só seriam permitidos mediante aprovação da autoridade consular, desde que o imigrante tivesse os "requisitos físicos e morais exigidos pela legislação em vigor" (BRASIL, 1941, artigo 3o, $\S 1^{\circ}$ ), obtendo, deste modo, “... aptidão para os trabalhos a que se propõe e condições de assimilação ao meio brasileiro" (BRASIL, 1941, artigo 3o, § $1^{\circ}$, grifo meu). Ou seja, era nula a ideia de incluir e integrar o imigrante à sociedade brasileira - respeitando suas culturas e características -, sem realizar neles imposições próprias do Brasil de cunho cultural ou de outra natureza.

Ideia semelhante foi aplicada no Decreto-Lei de n. 7.967, de 18 de setembro de 1945, que dispunha as diretrizes para a colonização e migração no Brasil, estabelecendo que a “... liberdade de ingresso do estrangeiro no Brasil" (SANT'ANA, 2001, p. 74) continuava assegurada desde que visasse as características de origem europeia defendendo, na mesma medida, o trabalhador nacional. A “imigração dirigida”, como trata o Decreto-Lei, possuía características restritivas, com ausência de liberdade do imigrante, se considerar que o imigrante que vinha ao Brasil com este propósito não poderia dedicar-se a outra atividade sem a liberação expressa das autoridades fiscalizadoras, como pode ser consultado no artigo de n. 45 :

Art. 45. O estrangeiro que houver entrado no Brasil no sistema da, imigração dirigida, a que se refere o artigo 38, tendo sido contratado para exercer trabalho determinado, não poderá, dentro do prazo contratual, salvo autorização do órgão competente e rescisão ou modificação da contrato, dedicar-se a atividade diferente. (BRASIL, 1945)

Este decreto foi revogado pela Lei n. 6.815, de 1980, que implementou o Estatuto do Estrangeiro. Porém, em virtude da discussão aqui empreendida sobre a migração europeia, convém citar o artigo segundo do decreto de 1945, mencionado anteriormente, o qual estabelecia que

Atender-se-á, na admissão dos imigrantes, à necessidade de preservar e desenvolver, na composição étnica da população, as características mais convenientes da sua ascendência européia, assim como a defesa do trabalhador nacional (BRASIL, 1945)

Até o final da década de 1950 e início da década de 1960, os países latinoamericanos, inclusive o Brasil, passaram a sair da rota migratória em geral, em razão da predileção por países considerados ricos, como os Estados Unidos, considerado rota preferencial no século 
XIX. Não que a migração para o Brasil deixou de acontecer, porém não em larga escala, como até então ocorria. É preciso ressaltar que nessa época as políticas de atração de imigrantes tal como vigoravam foram encerradas, dando lugar a uma nova fase da migração para o Brasil, considerada qualificada e com vistas a atuar em setores peculiares da economia brasileira. Durante o Regime Militar (1964-1985), a vinda de imigrantes foi encarada, principalmente, sob a égide da segurança nacional, excluindo desse modo pessoas que vinham ao país em busca de melhores condições de vida ou mesmo em busca de refúgio e/ou asilo (ASSIS \& MAGALHÃES, 2016).

Na década de 1980, com a criação do Estatuto do Estrangeiro, lei de número 6.815 de 19 de agosto de 1980, a migração persistiu ser vista juridicamente sob um viés produtivo, privilegiando a segurança nacional em detrimento de questões voltadas aos Direitos Humanos e, portanto, à humanização do processo imigratório para o Brasil. No artigo de número 16, a lei se refere à imigração como um meio de propiciar mão-de-obra especializada, em especial que esteja ligada ao aumento da produtividade, assim como a assimilação em âmbito tecnológico e captação de recursos (BRASIL, 1980).

Art. 65. É passível de expulsão o estrangeiro que, de qualquer forma, atentar contra a segurança nacional, a ordem política ou social, a tranqüilidade ou moralidade pública e a economia popular, ou cujo procedimento o torne nocivo à conveniência e aos interesses nacionais. (BRASIL, 1980)

Dois artigos em especial, segundo e terceiro, merecem atenção uma vez que por meio deles é possível compreender alguns entraves pelos quais o imigrante pode passar. Enquanto o artigo segundo determina que "na aplicação desta Lei atender-se-á precipuamente à segurança nacional, à organização institucional, aos interesses políticos, sócio-econômicos e culturais do Brasil, bem assim à defesa do trabalhador nacional" (BRASIL, 1980), o artigo terceiro, por sua vez, dispõe que "a concessão do visto, a sua prorrogação ou transformação ficarão sempre condicionadas aos interesses nacionais" (BRASIL, 1980). Assim sendo, por mais que se declare um país no qual os imigrantes podem entrar, não significa, porém, que terão o direito de permanecer.

Embora o Estatuto do Estrangeiro aparentemente não mencione alguma exigência de raça, etnia ou origem do imigrante que entre no Brasil, a herança propagada por leis anteriores, de características consideradas convenientes relacionadas aos imigrantes de origem europeia, ainda se faz vigente indiretamente na sociedade (SANT'ANA, 2001).

Após a instauração da Lei que rege o Estatuto dos Estrangeiros no Brasil, houve uma pressão por parte de organismos internacionais para que o Congresso Nacional brasileiro editasse a legislação, por intermédio da Lei de número 6.964 de dezembro de 1981. A medida foi necessária, uma vez que a lei de 1980 não levava em consideração “... os tratados internacionais e os direitos fundamentais da pessoa humana" (SPRANDEL, 2001, p. 98), corroborando para que 
“... a política de imigração possa ser traçada pelo Poder Executivo, sem o aval do Parlamento" (SPRANDEL, 2001, p. 98).

Desde então, a fim de executar os mecanismos disponíveis nas leis, a política migratória brasileira é exercida por órgãos específicos, entre os quais o Ministério da Justiça, o Ministério das Relações Exteriores, bem como o Ministério do Trabalho e Emprego, este último titular, ainda, do Conselho Nacional de Imigração (CNIg), responsável por articular a política migratória brasileira por meio da política de migração laboral.

A partir das primeiras décadas do século XXI com a mudança do governo no Brasil, à época presidido pelo presidente Luiz Inácio Lula da Silva, que possibilitou a melhora na economia e o desenvolvimento de programas de inclusão de cunho social, educativo e cultural, expandiu, dessa forma, o desenvolvimento econômico e internacional do país. Esse fator contribuiu para a chegada de grupos imigrantes, em especial os haitianos, sobretudo após a mudança na política migratória no que diz respeito a adoção, no Brasil, do visto humanitário, de forma que os acolhesse (ASSIS \& MAGALHÃES, 2016).

No entanto, haitianos e africanos passam, tanto na narrativa midiática quanto pela sociedade e políticas migratórias existentes, por um tratamento diferente no que diz respeito ao mesmo adotado para a atração de imigrantes europeus no passado. Não raro, são acompanhadas nas notícias sobre esses fluxos discursos de ódio, racismo e xenofobia feitos por representantes da sociedade civil nos espaços destinados aos comentários ou mesmo nas redes sociais, trazendo a tona a discussão em torno de um perfil desejado de imigrante. Sobre isso, Assis e Magalhães dizem que

A discriminação e preconceito a esse "outro" tão diferente na sua cultura, na sua cor, no seu modo de falar, na sua religião, colocam novos desafios de inclusão e diálogo intercultural para um Estado que construiu sua identidade muito pautada nas contribuições que trouxeram os imigrantes do século XIX, brancos e europeus e que agora recebe novos imigrantes vindos do Haiti e de outros países, os quais vem ao Brasil procurar oportunidades de trabalho e de reconstruírem suas vidas. (ASSIS \& MAGALHÃES, 2016, p. 246)

Há aqueles que vêm ao país e, ainda sem dispor de prerrogativas legais e direitos, a não ser documentos como carteira de trabalho, ocupam vagas laborais que geralmente não são requisitadas pelos nativos, como é o caso de imigrantes que atuam como pedreiros, em industrias com mão-de-obra braçal. Soma-se a isso o fato de também haver registro de casos onde vivem situações análogas à escravidão (ASSIS \& MAGALHÃES, 2016). Ou seja, contribuem para a economia, porém sem ter um retorno positivo ou a altura de seus anseios.

Em 2017 foi instituída uma nova Lei de Migração brasileira, sob o número 13.445, de 24 de maio de 2017, que substituiu o Estatuto do Estrangeiro de 1980. Em comparação com leis anteriores, representa avanços na legislação, no que diz respeito à garantias previstas pelos 
direitos humanos e para os trabalhadores imigrantes, cujos anseios não são amparados pelo Estatuto do Estrangeiro de 1980.

Diferente das leis aqui analisadas, a nova lei, no entanto, propõe-se a mudar a perspectiva sob a égide da segurança nacional, que vigorava no Estatuto do Estrangeiro de 1980. Dentre os avanços apontados na lei atual, segue-se uma breve descrição presente em seu artigo terceiro:

Art. $3^{\circ}$ A política migratória brasileira rege-se pelos seguintes princípios: I universalidade, indivisibilidade e interdependência dos direitos humanos; II - repúdio e prevenção à xenofobia, ao racismo e a quaisquer formas de discriminação; III - não criminalização da imigração; IV - não discriminação em razão dos critérios ou dos procedimentos pelos quais a pessoa foi admitida em território nacional; V - promoção de entrada regular e de regularização documental; VI - acolhida humanitária; VII - desenvolvimento econômico, turístico, social, cultural, esportivo, científico e tecnológico do Brasil; VIII - garantia do direito à reunião familiar; IX - igualdade de tratamento e de oportunidade ao migrante e seus familiares; $\mathrm{X}$ - inclusão social, laboral e produtiva do migrante por meio de políticas públicas; XI - acesso igualitário e livre do imigrante a serviços, programas e benefícios sociais, bens públicos, educação, assistência jurídica integral pública, trabalho, moradia, serviço bancário e seguridade social; XII - promoção e difusão de direitos, liberdades, garantias e obrigações do migrante; (...) (BRASIL, 2017)

A fim de traçar um paralelo entre os decretos e leis do passado e presente aqui analisados, cujos artigos descreviam claramente as características de um perfil desejado para os imigrantes, também tomou-se como fonte de análise reportagens realizadas na contemporaneidade por veículos jornalísticos brasileiros sobre os fluxos migratórios internacionais no país. Tal como acredita-se que a legislação possa ser considerada um lugar de memória, assim também o é o jornalismo, em suas diversas formas de manifestação e divulgação. Para Ana Paula Goulart Ribeiro, o jornalismo pode ser considerado um lugar de memória porque “... a mídia - sobretudo a jornalística - aponta, entre todos os fatos da atualidade, aqueles que devem ser memoráveis no futuro, reinvestindo-os de relevância histórica" (RIBEIRO, 2007, p. 7). Portanto, torna-se oportuno associar a discussão entre a revisão acerca da política migratória brasileira do passado e presente, com a cobertura midiática recente sobre os fluxos imigratórios contemporâneos. Em razão deste fator, foi realizada uma análise comparativa entre a referida legislação e discursos midiáticos publicados em sites de notícias, a fim de verificar pontos consonantes e dissonantes na referida legislação e que ainda emerge no presente. 


\section{Reflexos da política migratória brasileira na mídia}

Foi realizado um breve mapeamento com foco nas notícias publicadas a partir de 2010 até 2017. Diante da profusão de material jornalístico produzido durante o período contemplado para análise, foi necessário criar uma amostragem não-aleatória e estratificada. Para tanto, foram elegidas unidades de registro para guiar a coleta das reportagens no repositório online Google Notícias ${ }^{3}$, a partir do qual foi realizado o levantamento das reportagens. Herscovitz (2007) sugere algumas unidades de registro, que podem ser palavras, frases, temas, parágrafos presentes nas reportagens ou mesmo o texto inteiro. Nesta pesquisa foram adotadas a unidade de registro "imigrantes no Brasil", sendo selecionadas apenas as notícias cujas manchetes ou texto expusessem, de forma direta, tais palavras, retirando desse corpus aquelas cujo foco principal não tratasse da imigração ou que se referisse a fluxos imigratórios em outros países. Foram encontrados 417 resultados a partir do uso de tal unidade de registro dentro do período estabelecido (2010-2017). Destes resultados, deu-se preferência aos sites de veículos hegemônicos ${ }^{5}$ em detrimento de portais de notícias com menor relevância ou, ainda, postagens em redes sociais e blogs. Portanto, foi necessário selecionar apenas sites essencialmente jornalísticos e hegemônicos tais como Época, Terra, Veja, Carta Capital, dentre outros descritos na tabela 2 exposta adiante, resultando em uma seleção com 30 notícias.Para avaliar cada reportagem, resolveu-se adotar o método de Análise Crítica de Discurso (ACD) ${ }^{6}$ o qual pode ser utilizado para a análise de textos, sendo compreendidos como “... produções sociais historicamente situadas que dizem muito a respeito de nossas crenças, práticas, ideologias, atividades, relações interpessoais e identidades" (RESENDE \& RAMALHO, 2011, p. 10). Essa modalidade foi originada a partir da Teoria Social do Discurso, cujo expoente é o linguista britânico Norman Fairclough, para o qual assim como outros elementos e práticas sociais a linguagem também é um importante componente presente na vida social. Para as linguistas brasileiras Viviane de Melo Resende e Viviane Ramalho, esta teoria na qual a ACD foi fundada é “... capaz de mapear relações entre os recursos linguísticos utilizados por atores sociais e grupos de atores sociais e aspectos da rede de práticas em que a interação discursiva se insere" (RESENDE \& RAMALHO, 2011, p. 11-12). Para operacionalizar o método, considerou-se elementos textuais nas reportagens publicadas em sites jornalísticos, a partir das unidades de registro elegidas para a seleção das reportagens.

\footnotetext{
${ }^{3}$ As notícias foram mapeadas no período de janeiro a março de de 2017. O site pode ser acessado pelo seguinte link: https:// news.google.com.br/, sendo considerado um caminho viável para seleção de um número vasto e heterogêneo de notícias, no que diz respeito aos sites onde foram publicadas, visto que a seleção a partir do acesso individual a cada site de notícia demandaria um tempo maior de pesquisa.

${ }^{4}$ Neste caso, considerou-se os fluxos de imigrantes que foram visibilizados no discurso jornalístico aqui apontado. Ainda que mescle grupos com diferentes processos migratórios de ordem social e histórica, o resultado foi válido para mapear as abordagens jornalísticas acerca de imigrantes com perfis imigratórios distintos, e compará-los, em certa medida, com os perfis considerados desejados apontados em parte da legislação adotada no passado aqui analisadas.

${ }^{5}$ Considerando que tais veículos possuem abrangência e veiculação nacional em razão, também, de sua popularidade.

${ }^{6}$ Autores como Norman Fairclough e Teun Van Dijk adotaram a expressão Análise Crítica de Discurso, também conhecida pela sigla ACD. Outros pesquisadores, porém, utilizam-na na forma Análise de Discurso Crítica (ADC). Aqui, contudo, adotou-se a primeira.
} 
De um modo geral, notou-se quatro eixos temáticos predominantes sobre o macrotema "imigrantes no Brasil", e que versam sobre 1) aspecto legal das migrações (com referencia à legislação vigente); 2) migração vista enquanto problema, para o país e para os próprios imigrantes (com a aparição, inclusive, de casos de xenofobia, preconceito e racismo); 3) migração em números (neste caso, o destaque do texto ou manchete se dá para o número, crescimento ou decréscimo do número de imigrantes para o Brasil; e 4) migração sob o aspecto cultural e social (abordagens que enfatizam positivamente a cultura e o processo de inclusão e integração de imigrantes estrangeiros no país).

Tabela 1: Eixos temáticos observados no grupo de notícias selecionadas sobre imigrantes no Brasil (2010-2017)

\begin{tabular}{|l|c|}
\hline Aspecto legal das imigrações & 6 \\
\hline Imigração vista enquanto problema & 9 \\
\hline Imigração em números & 11 \\
\hline Imigração sob o aspecto cultural e social & 4 \\
\hline Total de notícias selecionadas & 30 \\
\hline
\end{tabular}

Fonte: produção própria da autora.

As notícias cujo enfoque seja o aumento ou decréscimo no número de imigrantes entrando e saindo do Brasil ficou em primeiro lugar, seguido do eixo da migração vista enquanto um problema, com nove notícias. Em terceiro as reportagens cujo enfoque foi a legislação, seja criticando ou elogiando e reforçando os critérios legais aplicados aos imigrantes e, por último, notícias que destacaram aspectos culturais e sociais desses imigrantes, no processo de inclusão e integração, em menor número. Notou-se, neste último caso, que notícias publicadas por entidades como a Organização das Nações Unidas (ONU), representada pela versão brasileira do seu site, surgiram em muitos momentos no sentido de esclarecer e promover a visibilidade de ações pró-imigrantes. Há que se reforçar que, no geral, sites de Organizações Não Governamentais (ONGs) promovem informação para educar e esclarecer os internautas sobre o que é a migração e os fatores que levam um imigrante a migrar. Considera-se que esta abordagem é importante para que a sociedade local possa entender e ter um olhar mais humanizado sobre o fenômeno das migrações.

Abaixo o total de fontes selecionadas. Foram separadas por eixo temático e apresentadas de acordo com a ordem cronológica crescente (de 2010 a 2017). 
Tabela 2: Notícias selecionadas sobre imigrantes no Brasil (2010-2017), por eixo temático

\begin{tabular}{|c|c|c|c|}
\hline \multicolumn{4}{|c|}{ Eixo temático: aspecto legal das imigrações } \\
\hline $\begin{array}{c}\text { Data da } \\
\text { publicação }\end{array}$ & Veículo & Manchete & Link da publicação \\
\hline 08/12/2014 & $\begin{array}{l}\text { Portal } \\
\text { Brasil }\end{array}$ & $\begin{array}{l}\text { Política brasileira de } \\
\text { imigração é exemplo a } \\
\text { outros países, afirma } \\
\text { relatório da OECD }\end{array}$ & $\begin{array}{l}\text { http://www.brasil.gov.br/economia-e- } \\
\text { emprego/2014/12/politica-brasileira-de- } \\
\text { imigracao-e-exemplo-a-outros-paises- } \\
\text { afirma-relatorio-da-oecd }\end{array}$ \\
\hline 07/07/2015 & Exame & $\begin{array}{l}\text { O panorama da imigração } \\
\text { no Brasil }\end{array}$ & $\begin{array}{l}\text { http://exame.abril.com.br/brasil/o- } \\
\text { panorama-da-imigracao-no-brasil/ }\end{array}$ \\
\hline $11 / 11 / 2016$ & Época & $\begin{array}{l}\text { Haitianos ganham mais } \\
\text { seis meses para regularizar } \\
\text { situação no Brasil }\end{array}$ & $\begin{array}{l}\text { http://epoca.globo.com/politica/ } \\
\text { expresso/noticia/2016/11/haitianos- } \\
\text { ganham-mais-seis-meses-para- } \\
\text { regularizar-situacao-no-brasil.html }\end{array}$ \\
\hline 07/12/2016 & $\begin{array}{l}\text { Agência } \\
\text { Brasil }\end{array}$ & $\begin{array}{l}\text { Entidades comemoram } \\
\text { aprovação da nova Lei de } \\
\text { Migração }\end{array}$ & $\begin{array}{l}\text { http://agenciabrasil.ebc.com.br/direitos- } \\
\text { humanos/noticia/2016-12/entidades- } \\
\text { comemoram-aprovacao-da-nova-lei-de- } \\
\text { migracao }\end{array}$ \\
\hline $17 / 02 / 2017$ & $\begin{array}{l}\text { Carta } \\
\text { Capital }\end{array}$ & $\begin{array}{l}\text { Migrações: por uma } \\
\text { legislação exemplar }\end{array}$ & $\begin{array}{l}\text { https://www.cartacapital.com.br/blogs/ } \\
\text { blog-do-grri/migracoes-por-uma- } \\
\text { legislacao-exemplar }\end{array}$ \\
\hline $11 / 03 / 2017$ & $\begin{array}{l}\text { Rádio } \\
\text { Agência } \\
\text { Nacional }\end{array}$ & $\begin{array}{l}\text { Brasil autoriza estrangeiros } \\
\text { de países que não integram } \\
\text { Mercosul a residir no país } \\
\text { por até dois anos }\end{array}$ & $\begin{array}{l}\text { http://radioagencianacional.ebc.com. } \\
\text { br/geral/audio/2017-03/brasil-autoriza- } \\
\text { estrangeiros-de-paises-que-nao- } \\
\text { integram-mercosul-residir-no-pais }\end{array}$ \\
\hline \multicolumn{4}{|c|}{ Eixo temático: imigração vista enquanto problema } \\
\hline $18 / 11 / 2013$ & EBC Brasil & $\begin{array}{l}\text { Destino de migrantes } \\
\text { haitianos continua } \\
\text { preocupando defensores de } \\
\text { direitos humanos }\end{array}$ & $\begin{array}{l}\text { http://www.ebc.com.br/noticias/ } \\
\text { colaborativo/2013/11/destino-de- } \\
\text { migrantes-haitianos-continua- } \\
\text { preocupando-defensores-de }\end{array}$ \\
\hline $13 / 05 / 2014$ & Terra & $\begin{array}{l}\text { Imigrantes haitianos sofrem } \\
\text { racismo e xenofobia no } \\
\text { Brasil }\end{array}$ & $\begin{array}{l}\text { https://noticias.terra.com.br/brasil/ } \\
\text { imigrantes-haitianos-sofrem-racismo-e- } \\
\text { xenofobia-no-brasil,a55e260ac95f5410Vg } \\
\text { nVCM10000098cceb0aRCRD.html }\end{array}$ \\
\hline 05/11/2015 & $\begin{array}{l}\text { Rede Brasil } \\
\text { Atual }\end{array}$ & $\begin{array}{l}\text { Preconceito é mais forte } \\
\text { contra migrantes vindos de } \\
\text { países pobres }\end{array}$ & $\begin{array}{l}\text { http://www.redebrasilatual.com.br/ } \\
\text { cidadania/2015/11/preconceito-tem-a-ver- } \\
\text { o-fato-de-refugiados-virem-de-paises- } \\
\text { pobres-diz-instituto-adus-8234.html }\end{array}$ \\
\hline
\end{tabular}




\begin{tabular}{|c|c|c|c|}
\hline $31 / 01 / 2016$ & $\begin{array}{l}\text { Repórter } \\
\text { Brasil }\end{array}$ & $\begin{array}{l}\text { "Alguns brasileiros tratam os } \\
\text { haitianos como escravos" }\end{array}$ & $\begin{array}{l}\text { http://reporterbrasil.org.br/2016/01/ } \\
\text { alguns-brasileiros-tratam-os-haitianos- } \\
\text { como-escravos-diz-lider-de-associacao- } \\
\text { de-imigrantes/ }\end{array}$ \\
\hline $04 / 08 / 2016$ & RFI & $\begin{array}{l}\text { Refugiados muçulmanos são } \\
\text { discriminados no Brasil }\end{array}$ & $\begin{array}{l}\text { http://br.rfi.fr/brasil/20160801- } \\
\text { refugiados-muculmanos-sao- } \\
\text { discriminados-no-brasil }\end{array}$ \\
\hline $11 / 08 / 2016$ & $\begin{array}{l}\text { Folha de } \\
\text { São Paulo }\end{array}$ & $\begin{array}{l}\text { Pesquisa revela alta rejeição } \\
\text { a refugiados e imigrantes no } \\
\text { mundo* }^{*}\end{array}$ & $\begin{array}{l}\text { http://www1.folha.uol.com.br/ } \\
\text { mundo/2016/08/1801673-pesquisa-revela- } \\
\text { alta-rejeicao-a-refugiados-e-imigrantes- } \\
\text { no-mundo.shtml }\end{array}$ \\
\hline $11 / 01 / 2017$ & Sul 21 & $\begin{array}{l}\text { Morte de mais um migrante } \\
\text { vítima de violência expõe } \\
\text { dificuldades e 'decepção' } \\
\text { com Brasil }\end{array}$ & $\begin{array}{l}\text { http://www.sul21.com.br/jornal/morte-de- } \\
\text { mais-um-migrante-vitima-de-violencia- } \\
\text { expoe-dificuldades-e-decepcao-com- } \\
\text { brasil/ }\end{array}$ \\
\hline $16 / 01 / 2017$ & Sul 21 & $\begin{array}{l}\text { Sem emprego, senegaleses } \\
\text { no mercado informal vivem } \\
\text { rotina de apreensões e } \\
\text { agressões }\end{array}$ & $\begin{array}{l}\text { http://www.sul21.com.br/jornal/sem- } \\
\text { emprego-senegaleses-no-mercado- } \\
\text { informal-vivem-rotina-de-apreensoes-e- } \\
\text { agressoes/ }\end{array}$ \\
\hline $18 / 02 / 2017$ & Veja & $\begin{array}{l}\text { Roraima espera maior } \\
\text { migração de venezuelanos } \\
\text { em } 2017\end{array}$ & $\begin{array}{l}\text { http://veja.abril.com.br/brasil/roraima- } \\
\text { espera-maior-migracao-de-venezuelanos- } \\
\text { este-ano/ }\end{array}$ \\
\hline \multicolumn{4}{|c|}{ Eixo temático: imigração em números } \\
\hline $17 / 08 / 2010$ & Terra & $\begin{array}{l}\text { Cai número de migrantes no } \\
\text { Brasil, diz estudo do Ipea }\end{array}$ & $\begin{array}{l}\text { https://noticias.terra.com.br/brasil/ } \\
\text { cai-numero-de-migrantes-no-brasil-diz- } \\
\text { estudo-do-ipea,612b4bc92690b310VgnCL } \\
\text { D200000bbcceb0aRCRD.html }\end{array}$ \\
\hline $27 / 04 / 2012$ & G1/Globo & $\begin{array}{l}\text { Número de imigrantes } \\
\text { cresceu 86,7\% em dez anos } \\
\text { no Brasil, diz IBGE }\end{array}$ & $\begin{array}{l}\text { http://g1.globo.com/brasil/ } \\
\text { noticia/2012/04/numero-de-imigrantes- } \\
\text { cresceu-867-em-dez-anos-no-brasil-diz- } \\
\text { ibge.html }\end{array}$ \\
\hline $13 / 11 / 2014$ & Zero Hora & $\begin{array}{l}\text { Brasil soma } 120 \text { mil } \\
\text { trabalhadores imigrantes }\end{array}$ & $\begin{array}{l}\text { http://zh.clicrbs.com.br/rs/noticias/ } \\
\text { noticia/2014/11/brasil-soma-120-mil- } \\
\text { trabalhadores-imigrantes-4641728.html }\end{array}$ \\
\hline $09 / 09 / 2015$ & $\mathrm{BBC}$ & $\begin{array}{l}\text { Brasil acolhe mais sírios que } \\
\text { países na rota europeia de } \\
\text { refugiados }\end{array}$ & $\begin{array}{l}\text { http://www.bbc.com/portuguese/ } \\
\text { noticias/2015/09/150904_brasil_- } \\
\text { refugiados_sirios_comparacao_- } \\
\text { internacional_lgb }\end{array}$ \\
\hline $01 / 12 / 2015$ & BBC & $\begin{array}{l}\text { Cai entrada de imigrantes no } \\
\text { Brasil, aponta pesquisa }\end{array}$ & $\begin{array}{l}\text { http://www.bbc.com/portuguese/ } \\
\text { noticias/2015/12/151201_imigracao_ } \\
\text { brasil_jc }\end{array}$ \\
\hline $26 / 08 / 2016$ & UOL & $\begin{array}{l}\text { Haitianos deixam Brasil e } \\
\text { geram crise migratória na } \\
\text { Costa Rica }\end{array}$ & $\begin{array}{l}\text { https://economia.uol.com.br/noticias/ } \\
\text { bloomberg/2016/08/26/haitianos- } \\
\text { deixam-brasil-e-geram-crise-migratoria- } \\
\text { na-costa-rica.htm }\end{array}$ \\
\hline
\end{tabular}

${ }^{*}$ Pesquisa apresentada na reportagem também destaca cenário brasileiro. Por este motivo, foi considerada na seleção. 


\begin{tabular}{|c|c|c|c|}
\hline $18 / 12 / 2016$ & $\begin{array}{l}\text { Folha de } \\
\text { São Paulo }\end{array}$ & $\begin{array}{l}\text { Diante de números recordes } \\
\text { de refugiados, Brasil precisa } \\
\text { ajudar mais }\end{array}$ & $\begin{array}{l}\text { http://www1.folha.uol.com.br/cenarios- } \\
\text { 2017/2016/12/1842081-diante-de-numeros- } \\
\text { recordes-de-refugiados-brasil-precisa- } \\
\text { ajudar-mais.shtml }\end{array}$ \\
\hline $20 / 12 / 2016$ & $\begin{array}{l}\text { Portal } \\
\text { Brasil }\end{array}$ & $\begin{array}{l}\text { Brasil recebeu mais de } 400 \\
\text { mil estrangeiros desde } 2013\end{array}$ & $\begin{array}{l}\text { http://www.brasil.gov.br/cidadania-e- } \\
\text { justica/2016/12/brasil-recebeu-mais-de- } \\
\text { 400-mil-estrangeiros-desde-2013 }\end{array}$ \\
\hline $07 / 12 / 2016$ & $\begin{array}{l}\text { Agência } \\
\text { Brasil }\end{array}$ & $\begin{array}{l}\text { Trabalhadores imigrantes } \\
\text { crescem } 131 \% \text { no Brasil de } \\
2010 \text { a } 2015\end{array}$ & $\begin{array}{l}\text { http://agenciabrasil.ebc.com.br/ } \\
\text { economia/noticia/2016-12/trabalhadores- } \\
\text { imigrantes-crescem-131-no-brasil- } \\
\text { de-2010-2015 }\end{array}$ \\
\hline $25 / 12 / 2016$ & G1/Globo & $\begin{array}{l}\text { Refugiados buscam emprego } \\
\text { no Brasil para mudar de } \\
\text { vida }^{* \star}\end{array}$ & $\begin{array}{l}\text { http://g1.globo.com/economia/concursos- } \\
\text { e-emprego/noticia/refugiados-buscam- } \\
\text { emprego-no-brasil-para-mudar-de-vida. } \\
\text { ghtml }\end{array}$ \\
\hline $15 / 02 / 2017$ & $\begin{array}{l}\text { Rádio } \\
\text { Agência } \\
\text { Nacional }\end{array}$ & $\begin{array}{l}\text { Em um ano, migração } \\
\text { venezuelana para o Brasil } \\
\text { cresceu } 3.000 \%\end{array}$ & $\begin{array}{l}\text { http://radioagencianacional.ebc.com. } \\
\text { br/geral/audio/2017-02/em-um-ano- } \\
\text { migracao-venezuelana-para-o-brasil- } \\
\text { cresceu-3000 }\end{array}$ \\
\hline \multicolumn{4}{|c|}{ Eixo temático: imigração sob o aspecto cultural e social } \\
\hline $16 / 08 / 2014$ & Zero Hora & $\begin{array}{l}\text { Novos imigrantes mudam o } \\
\text { cenário do Rio Grande do Sul }\end{array}$ & $\begin{array}{l}\text { http://zh.clicrbs.com.br/rs/noticias/ } \\
\text { noticia/2014/08/novos-imigrantes- } \\
\text { mudam-o-cenario-do-rio-grande-do- } \\
\text { sul-4576728.html }\end{array}$ \\
\hline 09/06/2015 & G1/Globo & $\begin{array}{l}\text { Refugiados gravam música } \\
\text { e vídeo em que agradecem } \\
\text { abrigo no Brasil }\end{array}$ & $\begin{array}{l}\text { http://g1.globo.com/mundo/ } \\
\text { noticia/2015/06/refugiados-gravam- } \\
\text { musica-e-video-em-que-agradecem- } \\
\text { abrigo-no-brasil.html }\end{array}$ \\
\hline 03/05/3016 & ONU Brasil & $\begin{array}{l}\text { Qual a diferença entre } \\
\text { 'refugiados'e 'migrantes'? }\end{array}$ & $\begin{array}{l}\text { https://nacoesunidas.org/qual-a- } \\
\text { diferenca-entre-refugiados-migrantes/ }\end{array}$ \\
\hline $21 / 04 / 2016$ & $\begin{array}{l}\text { Deutsche } \\
\text { Welle (DW) }\end{array}$ & $\begin{array}{l}\text { "Temos que compreender } \\
\text { fluxo de refugiados como } \\
\text { uma oportunidade" }\end{array}$ & $\begin{array}{l}\text { http://www.dw.com/pt-br/temos-que- } \\
\text { compreender-fluxo-de-refugiados-como- } \\
\text { uma-oportunidade/a-19203315 }\end{array}$ \\
\hline
\end{tabular}

${ }^{* *}$ Reportagem destaca número de refugiados vindos para o Brasil nos últimos anos.

Fonte: produção própria da autora. 
Das fontes selecionadas no corpus de análise e acima expostas, destacou-se alguns trechos sobre as notícias, sobretudo aquelas que abarcam a imigração sob o aspecto legal, contextualizando com a análise da legislação apresentada anteriormente.

A notícia intitulada "Brasil autoriza estrangeiros de países que não integram Mercosul a residir no país por até dois anos", publicada pela Rádio Agência Nacional em 11 de março de 2017, apresentou algumas questões legais exigidas pela legislação para que um imigrante permaneça no Brasil. Atualmente, são exigidos ao imigrante documentos como a certidão negativa de antecedentes criminais, além de declarar que não foi processado anteriormente, quando em seu país de origem. Ou seja, ao passo que a instrução normativa do Conselho Nacional de Imigração preveja meios para a inclusão e integração do imigrante, na mesma medida só é válida para aqueles que dispõem de uma conduta considerada moralmente adequada, tal como praticado no passado em leis aqui revistas anteriormente.

O artigo publicado na edição online da revista Carta Capital em 17 de fevereiro de 2017, intitulado "Migrações: por uma legislação exemplar", destacou as melhorias que podem ser alcançadas aos imigrantes com a aprovação da nova Lei de Migrações, em contraponto ao "retrógrado Estatuto do Estrangeiro". Como exemplo, citou o caso dos haitianos. A época do aumento no fluxo imigratório desse grupo para o Brasil, especialmente após 2010, quando do terremoto ocorrido no Haiti, o Governo Federal se tomou medidas necessárias para a inclusão deste grupo, uma vez que não se adequavam nas prerrogativas legais da situação de refúgio, por eles requisitada em virtude da vulnerabilidade que se encontravam naquele momento. Se aprovada, a nova lei também irá combater diretamente a xenofobia. Um dos fatores primordiais não disponíveis em leis e decretos anteriores é condenar e repudiar os atos discriminatórios, de caráter preconceituoso e/ou racista, ou ainda de teor xenofóbico contra os imigrantes, sobretudo os provenientes de fluxos imigratórios contemporâneos, como é o caso dos imigrantes haitianos, por exemplo. "De acordo com dados do Disque 100 da Secretaria Especial de Direitos Humanos do governo federal, as denúncias de violência contra migrantes aumentaram 633\% em 2015. A existência de um marco legal positivo, portanto, é fundamental para proteger essas pessoas" (VARGEM \& ASANO, 2017).

Embora a análise tenha sido realizada de forma breve, foi possível evidenciar no recorte temporal selecionado (2010-2017) a presença de um discurso midiático que ora marginaliza as migrações, apontando problemas provenientes com a chegada e permanência dos fluxos, ora tenta sensibilizar seu público-leitor a entender o que leva uma pessoa a migrar. Inclusive apontou, seja por meio de artigos publicados por representantes da sociedade civil ou reportagens feitas por jornalistas, medidas tomadas pelo Governo Federal para driblar a política migratória vigente, que não atende plenamente as necessidades dos fluxos imigratórios contemporâneos no Brasil. 


\section{Considerações finais}

As imigrações foram introjetadas no imaginário da sociedade brasileira de duas formas: sendo o Brasil um país do qual emigram muitos nacionais, como aconteceu e acontece com brasileiros que optam sair do país, e do Brasil enquanto destino de fluxos imigratórios europeus entre os séculos XIX e XX. Perfis imigratórios que fogem dessa última perspectiva são, portanto, compreendidos como o outro. Este estranhamento, em diversas vezes, pode ocorrer no sentido de desqualificar os fluxos imigratórios, sobretudo os contemporâneos (COGO \& SOUZA, 2013).

Ao contextualizar a questão com outros estudos sobre as imigrações, Gláucia de Oliveira Assis e Elisa Massae Sasaki argumentam que "os migrantes de todos os tempos evocam diversas imagens" (ASSIS \& SASAKI, 2000, p. 1). Ao analisarem a imigração nos Estados Unidos entre os séculos XIX e XX, algumas das imagens vinculavam os imigrantes a fatores como a criminalidade, a desagregação social, a construção de uma nova vida em guetos com outros conterrâneos. Ainda que digam respeito a séculos anteriores, o que se nota, porém, é que tais imagens continuam a ser evocadas no que diz respeito a determinados grupos imigrantes contemporâneos.

É importante ressaltar que quem imigra não o faz apenas em virtudes econômicas dos países envolvidos (onde se encontra e para o qual se deseja migrar) ou com relação a pobreza. Ao basear sua análise na nova economia das migrações laborais, Castles evidencia que a decisão de migrar ou não envolve além da motivação pessoal, questões familiares, dentre outros fatores presentes no meio no qual o imigrante vive, entre homens e mulheres, tais como o desemprego ou a ausência de oportunidades que abarquem as expertises de cada um, assim como os riscos de longo prazo no empreendimento de um novo negócio (CASTLES, 2005). O desconhecimento dessa premissa pode reforçar, seja por parte da mídia ou da própria sociedade que dela se informa, preconceitos, racismo e xenofobia contra os fluxos imigratórios contemporâneos.

Os acontecimentos envolvendo imigrantes vindos para o Brasil nas duas primeiras décadas do século XXI evocam imaginários sociais sobre as grandes imigrações ocorridas no passado, os quais podem ser envoltos em discursos que legitimam as do passado em detrimento das contemporâneas, em razão de a legislação brasileira, em momentos distintos no decorrer dos séculos XIX e XX, ter legitimado determinados perfis imigrantes e grupos imigratórios considerados como aceitos para o desenvolvimento do país em detrimento de outros. Logo, esse discurso transcendeu a esfera jurídica e ganhou, de certa forma, guarida nos discursos midiáticos e sociais.

Não se quer dizer, com isso, que os imigrantes do passado não passaram por dificuldades ou foram vítimas como os da contemporaneidade, sobretudo o que passam os de origem africana ou negros de outras nacionalidades. Porém, é inegável que, a partir do momento que perfis de 
imigrantes são privilegiados em detrimento de outros, passam portanto a ocupar um espaço positivamente singular.

Se no passado grupos imigrantes formados, sobretudo, por europeus, foram requisitados inclusive em esfera legal para transformar uma vaga ideia de nação brasileira, a partir da ideologia de branqueamento, na atualidade se percebe que parte dos integrantes de imigrantes que vêm para o Brasil são vistos como "ladrões de empregos" ou aqueles que "vêm sobrecarregar o país em um momento de crise econômica e política", dentre outros discursos presentes em comentários em sites de notícias ou nas redes sociais.

Quando as políticas migratórias são evocadas, seja diretamente pelos decretos e leis com seu sentido explícito ou latente, seja através dos discursos sociais e midiáticos, essa memória em torno da imigração no Brasil é invocada no sentido de legitimar determinados grupos imigrantes (por exemplo os europeus, que "construíram" o Brasil) em detrimento dos contemporâneos ("em massa", para "roubar" empregos). Tal ideia se cristaliza nos decretos e leis que vigoraram anteriormente e que ainda podem ser constatadas para entender porque determinados grupos foram legitimados no passado. No caso dos decretos e leis e dos discursos midiáticos que as reforçam, é preciso refletir que este lugar que a memória outorga um espaço já não é memória, senão história nas mãos daqueles que lhes dedicam tempo e análise crítica.

Em síntese, com base no exposto por Pierre Nora (1993), considera-se que tanto decretos quanto as leis podem ser lugares de memória a partir do momento em que continuam a existir, mesmo sem um efeito direto sobre as ações das quais regiram em um passado, distante ou recente. Mais: em seu processo de atualização, quando não são revogadas, continuam a persistir no tempo sob outra roupagem. Mudam-se as palavras, os artigos, os apêndices, mas o sentido permanece, ora oculto e latente, ora escancarado.

Ainda que seja possível reler e analisar os decretos e leis, no geral não são recapituladas em sua integralidade, tampouco interpretadas de modo a criticar o modo como determinavam quem era ou não digno de poder entrar e viver no Brasil. Os preconceitos eram e são marcantes, mesmo que atualmente sob outra roupagem e nomenclatura.

\section{Referências}

\section{Fontes}

BRASIL. Decreto n. 80 sobre Estrangeiros, publicado em 31 de março de 1824. In: IMPRENSA NACIONAL. Collecção das Decisões do Governo do Imperio do Brazil de 1824. Rio de Janeiro: Typographia Nacional, 1886, p. 58. Disponível em: <http://bd.camara.gov.br/bd/handle/ bdcamara/18340>. Acesso em: 22 fev. 2017. 
BRASIL. Lei n. 601, de 18 de setembro de 1850. Dispõe sobre as terras devolutas do Império. Livro $1^{\circ}$ dos Actos Legislativos, Rio de Janeiro, RJ, 2 out. 1850. Disponível em: <http://www. planalto.gov.br/ccivil_03/LEIS/L0601-1850.htm>. Acesso em: 22 fev., 2017.

BRASIL. Decreto n. 528, de 28 de junho de 1890. Regulariza o serviço de introdução e localização de imigrantes na República dos Estados Unidos do Brasil. Coleção de Leis do Brasil - 1890. Disponível em: <http://www2.camara.leg.br/legin/fed/decret/1824-1899/decreto-528-28-junho1890-506935-publicacaooriginal-1-pe.html>. Acesso em: 22 fev. 2017.

BRASIL. Decreto n. 9.081 de 3 de novembro de 1911. Dá novo regulamento ao Serviço de Povoamento. Diário Oficial da União - Seção 1, Rio de Janeiro, RJ, 23 dez. 1911. Disponível em: <http://www2.camara.leg.br/legin/fed/decret/1910-1919/decreto-9081-3-novembro-1911523578-republicacao-102836-pe.html>. Acesso em: 22 fev. 2017.

BRASIL. Decreto de número 4.247, publicado em 6 de janeiro de 1921. Regula a entrada de estrangeiros no território nacional. Diário Oficial da União - Seção 1, Rio de Janeiro, RJ, 8 jan. 1921. Disponível em: <http://www2.camara.leg.br/legin/fed/decret/1920-1929/decreto-4247-6janeiro-1921-568826-publicacaooriginal-92146-pl.html>. Acesso em: 22 fev. 2017.

BRASIL. Decreto-Lei número 406, de 4 de maio de 1938. Dispõe sobre a entrada de estrangeiros no território nacional. Diário Oficial da União - Seção 1, Rio de Janeiro, RJ, 6 mai. 1938a. Disponível em:

<http://www2.camara.leg.br/legin/fed/declei/1930-1939/decreto-lei-406-4-maio-1938-348724publicacaooriginal-1-pe.html>. Acesso em: 22 fev. 2017.

BRASIL. Decreto n. 3.010, de 20 de Agosto de 1938. Regulamenta o decreto-lei n. 406, de 4 de maio de 1938, que dispõe sobre a entrada de estrangeiros no território nacional. Diário Oficial da União - Seção 1, Rio de Janeiro, RJ, 22 ago. 1938b. Disponível em: < http://www2.camara.leg. br/legin/fed/decret/1930-1939/decreto-3010-20-agosto-1938-348850-publicacaooriginal-1-pe. html>. Acesso em: 22 fev. 2017.

BRASIL. Decreto-Lei, de número 3.175, de 1941. Restringe a imigração e dá outras providências. Diário Oficial da União - Seção 1, Rio de Janeiro, RJ, 9 abr. 1941. Disponível em: <http:// www2.camara.leg.br/legin/fed/declei/1940-1949/decreto-lei-3175-7-abril-1941-413194publicacaooriginal-1-pe.html>. Acesso em: 31 mar. 2017. 
BRASIL. Decreto-Lei de n.7.967, de 18 de setembro de 1945. Dispõe sobre a Imigração e Colonização e dá outras providências. Coleções de Leis do Brasil, Rio de Janeiro, RJ, 31 dez. 1945. Disponível em: <http://www.planalto.gov.br/ccivil_03/decreto-lei/1937-1946/Del7967.htm>. Acesso em: 31 mar. 2017.

BRASIL. Lei n. 6.815, de 1980. Define a situação jurídica do estrangeiro no Brasil, cria o Conselho Nacional de Imigração. Diário Oficial da União, Brasília, DF, 21 ago. 1980. Disponível em: <http://www.planalto.gov.br/ccivil_03/leis/L6815.htm>. Acesso em: 31 mar. 2017.

BRASIL. Lei n. 13.445, de 24 de maio de 2017. Institui a nova Lei de Migração. Planalto. Disponível em: <http://www.planalto.gov.br/ccivil_03/_Ato2015-2018/2017/Lei/L13445.htm>. Acesso em: 10 jul. 2017.

\section{Bibliografia}

ASSIS, Gláucia de Oliveira. De Criciúma para o Mundo: Rearranjos familiares de novos migrantes brasileiros. Florianópolis: Editora Mulheres, 2012.

ASSIS, Gláucia de Oliveira; MAGALHÃES, Luís Felipe Aires. Migrantes indesejados? A “diáspora" haitiana no Brasil e os desafios à política migratória brasileira. In: SILVA, Sidney da; ASSIS, Gláucia de Oliveira (orgs.). Em busca do Eldorado: o Brasil no contexto das migrações nacionais e internacionais. Manaus: EDUA, 2016, p. 209-250.

ASSIS, Gláucia de Oliveira; SASAKI, Elisa Massae. Teoria das Migrações Internacionais. Associação Brasileira de Estudos Populacionais (ABEP). Caxambu/MG: 2000. Disponível em: <http://www.abep.nepo.unicamp.br/docs/anais/pdf/2000/Todos/migt16_2.pdf>. Acesso em: 24 nov. 2014.

BARRETO, Luiz Paulo Teles Ferreira. Considerações sobre a imigração no Brasil contemporâneo. In: CASTRO, Mary Garcia (coord.). Migrações Internacionais: Contribuições para Políticas. Brasília: Comissão Nacional de População e Desenvolvimento (CNPD), 2001, p. 63-71.

CARONE, Iray. Breve histórico de uma pesquisa psicossocial sobre a questão racial brasileira. In: CARONE, Iray; BENTO, Maria Aparecida Silva (orgs.). Psicologia social do racismo: estudos sobre branquitude e branqueamento. Petrópolis/RJ: Vozes, 2002, p. 13-23.

CASTLES, Stephen. As migrações internacionais no limiar do século XXI: questões e tendências globais. In: _. _._._. Globalização, transnacionalismo e novos fluxos migratórios: os trabalhadores convidados às migrações globais. Lisboa: Fim de Século, 2005, p. 15-43. 
COGO, Denise; SOUZA, Maria Badet. Guia das Migrações Transnacionais e Diversidade Cultural para Comunicadores - Migrantes no Brasil. Belatterra: Instituto de la Comunicación de la UAB/Instituto Humanitas Unisinos, 2013.

HALBWACHS, Maurice. A memória coletiva. São Paulo: Edições Vértice - Editora Revista dos Tribunais LTDA., 1990.

HERSCOVITZ, Heloiza Golbspan. Análise de conteúdo em jornalismo. In: LAGO, Cláudia; BENETTI, Marcia (orgs.). Metolodogia de pesquisa em jornalismo. Petrópolis/RJ: Vozes, 2007, p. 123-142.

MARINGONI, Gilberto. História - O destino dos negros após a Abolição. Revista Desafios do Desenvolvimento. Instituto de Pesquisa Econômica Aplicada (IPEA), ano 8, edição 70, 29 dez. 2011. Disponível em: <http://www.ipea.gov.br/desafios/index.php?option=com_content\&id=2 673\%3Acatid\%3D28\&Itemid=23>. Acesso em: 31 mar. 2017.

MENEZES, Lená Medeiros de. Movimentos e Políticas Migratórias em Perspectiva Histórica: Um balanço do século XX. In: CASTRO, Mary Garcia (coord.). Migrações Internacionais: Contribuições para Políticas. Brasília: Comissão Nacional de População e Desenvolvimento (CNPD), 2001, p. 123-136.

MUNANGA, Kabengele. Prefácio. In: CARONE, Iray; BENTO, Maria Aparecida Silva (orgs.). Psicologia social do racismo: estudos sobre branquitude e branqueamento. Petrópolis/RJ: Vozes, 2002, p. 9-11.

NORA, Pierre. Entre memória e história: a problemática dos lugares. Revista Proj. História. São Paulo, (10), dez. 1993, p. 7-28.

RESENDE, Viviane de Melo; RAMALHO, Viviane. Análise de Discurso Crítica. 2. ed. São Paulo: Contexto, 2011.

RIBEIRO, Ana Paula Goulart; FERREIRA, Lucia Maria Alves (orgs.). Mídia e memória: a produção de sentidos nos meios de comunicação. Rio de Janeiro, Mauad X, 2007.

SANT'ANA, Marcílio Ribeiro de. Livre circulação de trabalhadores no Mercosul? In: CASTRO, Mary Garcia (coord.). Migrações Internacionais: Contribuições para Políticas. Brasília: Comissão Nacional de População e Desenvolvimento (CNPD), 2001, p. 73-93. 
SEYFERTH, Giralda. Identidade Étnica, Assimilação e Cidadania: A Imigração Alemã e o Estado Brasileiro. Revista Brasileira de Ciências Sociais, v. 9, n. 26, p. 103-122, 1994. Disponível em: $<$ http://www.igtf.rs.gov.br/wp-content/uploads/2012/10/IDENTIDADE-ÉTNICA.pdf $>$. Acesso em: 15 jun. 2016.

. Imigração no Brasil: os preceitos da exclusão. Revista ComCiência (SBPC/Labjor), n. 16, dez./2000. Disponível em:

<http://www.comciencia.br/reportagens/migracoes/migr03.htm>. Acesso em: 27 maio 2016.

Imigração e nacionalismo: o discurso da exclusão e a política imigratória no Brasil. In: CASTRO, Mary Garcia (coord.). Migrações Internacionais: Contribuições para Políticas. Brasília: Comissão Nacional de População e Desenvolvimento (CNPD), 2001, p. 137150.

SPRANDEL, Marcia. O Parlamento e as migrações internacionais. In: CASTRO, Mary Garcia (coord.). Migrações Internacionais: Contribuições para Políticas. Brasília: Comissão Nacional de População e Desenvolvimento (CNPD), 2001, p. 97-119.

VARGEM, Alex André; ASANO, Camila Lissa. Migrações: por uma legislação exemplar. Carta Capital, 16 fev. 2017. Disponível em: <https://www.cartacapital.com.br/blogs/blog-do-grri/ migracoes-por-uma-legislacao-exemplar >. Acesso em: 22 fev. 2017. 